\title{
School Engagement and Civic Engagement as Predictors for the Future Political Participation of Ethnic Chinese and South Asian Adolescents in Hong Kong
}

DOI: $10.11567 /$ met.29.3.1

UDK: 323.2:316.32]-057.874(512.317=581)

323.2:316.32]-054.72-057.874(512.317:5-13)

Prethodno priopćenje

Primljeno: 10.10. 2013.

Prihvaćeno: 30.1.2014.

Celeste Y. M. Yuen

Department of the Education Policy and Leadership, The Hong Kong Institute of Education, Hong Kong

ymyuen@ied.edu.hk

\section{SUMMARY}

This paper reports the findings of a large study on the relationship between school and civic engagement and the self-perceived participation in political activities of ethnic Chinese and South Asian immigrant students in Hong Kong. Data was collected from a sample of $5,5746^{\text {th }}-11^{\text {th }}$ graders aged $12-19$. The nature of school engagement was assessed by a self-rated questionnaire against the affective, behavioral and cognitive domains. Students' civic engagement was measured by the ICCS student questionnaire (Schulz et al., 2009). Before running the regression analyses, Confirmatory Factor Analysis (CFA) was performed and the results showed that both instruments had good construct validity and internal consistency. Consistent with the primary aim of this study, MANOVA analyses indicate significant student group differences in school engagement, and civic related self-belief and behaviours. Our findings showed that non-Chinese speaking South Asian students (NCS) scored higher than their mainstream Chinese and newly arrived students from Mainland China (NAS) counterparts across the dimensions of both instruments. Results of hierarchical regressions confirmed that school engagement was significant in predicting expected political participation in the future. The effects of school and civic engagement on future political participation varied significantly between all studied groups.

KEY WORDS: school engagement, civic engagement, political participation, ethnic Chinese, immigrants, adolescents, Hong Kong

\section{INTRODUCTION}

Student engagement with school has been internationally recognized as a key factor influencing the academic performance of all students (Apple- 
ton, Christenson and Furlong, 2008; Fredricks, Blumenfeld and Paris, 2004; Hart, Stewart and Jimerson, 2011). It is linked to students' pro-school affection, behaviours and cognition and academic performance. Promoting positive school engagement means advocating effective schooling for all. International studies show that civic engagement is positively correlated with good attendance, a higher grade point average (GPA), higher self-esteem and higher academic self-efficacy (Perez et al., 2010; Eccles and Barber, 1999). Schools are the best places for studying civic engagement as they are the most diverse environments that young people inhabit and where they are exposed to a range of views on controversial issues and current affairs. School culture not only reflects civic culture but is also a shaper of civic culture. For example, an inclusive school culture will encourage an inclusive civic culture in the students as future citizens, and vice versa.

Education is seen as a social leveller especially for the socially disadvantaged. The government should be held accountable for the legal entitlements of all children in school and civic engagement (Lansdown, 2010). The Working Group on Education for Ethnic Minorities (Equal Opportunities Commission, 2011) points out that ethnic minority students are disproportionally low in numbers compared with the local Chinese majority and only account for $3.2 \%$ of the total student population at the pre-primary level and $1.1 \%$ at the upper secondary level in Hong Kong. In a recent policy response, a special annual grant ranging from $\$ 300,000$ to $\$ 600,000$ was allocated to each designated school (i.e., not less than $30 \%$ of non-Chinese speaking students) to sponsor school-based support programmes (Education Bureau, 2010). But public debates on the handicaps facing ethnic South Asians in learning Chinese have highlighted their educational and social challenges (Shum, Gao and Tsung, 2011; Tsung, Zhang and Cruickshank, 2010; Hong Kong Unison, 2011a, b). As for the newly arrived students from Mainland China, the issues of over-age placement, poverty and dysfunctional family conditions seriously inhibit their academic self-esteem and school performance (Yuen, 2004a, b, 2009). Moreover, public discussions on cross-boundary students are usually centred around long travelling hours, inadequate homework support from family, single parenting and challenging home-school coordination (Bauhinia Foundation Research Centre, 2009; Yuen, 2009, 2010a, b, 2011). The nature and the extent of the engagement of minority and immigrant students with their schools and Hong Kong society together are important indicators of social inclusion policy.

As outlined in their Policy Addresses of 2010/11 and 2011/12, the Home Affairs Department was entrusted by the government with the launching 
of a series of district-based integration programmes for preparing prospective new immigrants from Mainland China and South Asia for relocating to Hong Kong. A special radio programme for ethnic minorities is being instituted. An additional $\$ 20$ million has been allocated to NGOs to provide comprehensive community support activities etc. Such initiatives suggest that the government is heading towards an inclusive society for all. Moreover, in the newly published 2014 Policy Address, this message has been reiterated and a new service centre to serve the ethnic community was proposed. These new initiatives, however, have yet to be reviewed, and media coverage of immigrant and minority youth tends to be negative and stigmatizing. Local studies reveal that South Asian people experience different kinds of social exclusion (Shum, Gao and Tsung, 2011; Ku, Chan and Sandhu, 2005). Since only discrete public knowledge of our minority youth's situation in civic engagement is available, it is difficult to determine the extent to which the intended outcomes are being yielded.

\section{THEORETICAL FRAMEWORK}

Minority students also need to develop new political responsibilities and be provided with opportunities appropriate to their new social contexts (Levine and Youniss, 2006). They are full citizens and school is a training ground for civic mindedness. Students engage with civic society both inside and outside of school. School engagement is not disassociated from civic engagement; rather the one reflects the other. This is an extension of the point already made that schools are a reflection of civic society.

Studies on school engagement and civic engagement conclude that they are both tightly linked with individuals' cognitive, affective and behavioural dimensions. For example, in Finn's model $(1989,1993)$, student participation in and identification with the school is moderated by the consequence. Put another way, positive feedback leads to positive engagement. Fredricks et al. (2005), and Jimerson, Campos and Greif (2003) underscore the role of the cognitive dimension in learning and their subjective assessment in self, school, teachers and peers. Studies of Skinner and Belmont (1993) as well as Elmore and Huebner (2010) indicate that engagement with school is positively correlated with social and contextual factors. Adolescents are at the critical stage in identity seeking and friendship at school is a key contributor to strengthening their emotional attachment to school and learning. Relationship with teachers is another factor that mediates the amount of individual effort put into education. Pleasant and fulfilling school experi- 
ences promote greater life satisfaction among adolescents, especially given that they spend a large portion of their time at school.

Research findings of immigrant studies have concluded that parental involvement is a strong predictive index for immigrant children's learning (Hong and Ho, 2005; Drummond and Stipek, 2004; Rumbaut, 2000; Fan, 2001). Fan and Chen's (2001) study measures differences in parental involvement among the major ethnic groups and reveals that parental aspirations/expectations for children's academic achievement have the strongest effects on their learning outcomes. Chinese parents generally value academic achievement more than other ethnic groups, believing that education is the chief avenue to their children's upward social mobility (Eng, 1995).

Torney-Purta (2002) reminds us that school is the place where civic education goals are pursued and that has been charged with a responsibility to further these goals. Students engage with civic society both inside and outside of school. Her study on school's role in developing civic engagement of adolescents from 28 countries concludes that students from homes with few literacy or educational resources have relatively low levels of civic knowledge and willingness for social participation.

Adler and Goggin (2005) define civic engagement as the way in which citizens engage in activities to improve the lives of others and help shape the community's future. Other scholars regard civic engagement as community service (Diller, 2001), collective action (Van Benshoten, 2001) and political involvement (Ronan, 2004). Whiteley (2012) argues that civic engagement refers to the participation in voluntary political activities. In a broader sense, civic engagement is "experiencing a sense of connection, interrelatedness, and, naturally, commitment towards the greater community (all life forms)" (Diller, 2001: 22). Hart and Kirshner (2009) reaffirmed that engaged citizenship consists of several core elements: civic knowledge, civic attitude, and civic action.

The work of Youniss, McLellan and Mazer (2001) reveals that both voluntary service and peer group orientation are factors affecting the differentiated civic engagement of students. No consistent results have been reached among the international studies on the civic engagement of immigrant youth. For example, Lopez and Marcelo's (2008) data from the 2006 Civic and Political Health of the National Survey conducted by CIRCLE provides evidence that young immigrants have a lower level of civic engagement on most measures compared to local-born Americans. Education, socio-economic status and English language proficiency are found to be strong predictors. If the demographic factors were controlled, immigrant 
youth were more likely to be civically disengaged. By contrast, work of A. Stepick, C. Stepick and Labissiere (2008) on Florida immigrant youth concludes that there is no significant difference in any measures taken on the political, civic, expressive and social engagement between them and their local-born American counterparts. However, specific patterns of engagement are discussed. More attention and effort is paid to the activities that relate to their own ethnic community, such as assisting new arrivals from their culture of origin, than on the broader national scale. Other research indicates that religion also plays an important role in immigrant civic engagement (Stepick, 2005). Apart from the work of Stepick et al., the study of Perez et al. (2010) confirms as well that there is a high level of civic engagement among foreign-born undocumented youth in the United States. A very positive picture was found among the youth - one that showed that they are politically active, although they are not regarded as full citizens because of their legal status. Gender and grade are both mediating factors in the level and type of civic engagement of these youth. As a complement to the quantitative studies on civic engagement, Jensen's (2008) qualitative data reveal that immigrant parents and adolescents engage themselves more at the community level than at the political level. The nature of their engagement behaviour reflects a kind of bicultural consciousness and experience, which is seen to be a contributing factor rather than an inhibiting factor influencing their civic engagement.

The above studies can help us to demystify the social perception that immigrant youth are normally socially withdrawn or disengaged. Instead, their contribution to civic engagement and community building has been recognized. In other words, with the right avenues and empowerment, immigrant minority youth are or can be productive citizens of their host society contributing to both its mainstream and ethnic communities. They may be considered to be engaged rather than disengaged when compared with their local-born peers.

Likewise, there are numerous media news stories in Hong Kong associating minority youth with school disengagement and/or social disengagement because of their disadvantageous social and family conditions (Lee, 2013; Tsui, 2013). In terms of school engagement, public debates are predominantly centred on learning Chinese as a second language (Tsung, Zhang and Cruickshank, 2010; Hong Kong Unison, 2011a, b). The work of $\mathrm{Ku}$, Chan and Sandhu (2005), for example, showed that ethnic South Asians perceived themselves as Hong Kong citizens and expressed an interest in engaging in the local community. Their discontentment with the existing 
Chinese Language policy could be seen as their desire for greater social inclusion and recognition. South Asians came from a culture strongly oriented towards family and community. Similarly, new Chinese immigrants have a strong sense of kinship ties.

While the above studies have extensively reviewed civil engagement and school engagement, the two elements have been analyzed separately and many of the more relevant studies, particularly those concerned with civic engagement, have been conducted within a North American context. Consequently there is a lack of discussion on the linkage between these two areas and especially with regard to Hong Kong's particular circumstances. This proposed study, therefore, attempts to search for answers to the following questions: Are there marked differences in school and civic engagement between South Asian and new Chinese immigrant students? Does student engagement with school and civic society have any effects on their civic participation in the future?

\section{METHOD}

\section{Participants and Procedure}

A sample of 5574 students, aged between 12 and 19, were invited to participate in the study. Parental consent was provided for all participants before conducting the questionnaire survey. Given the specific research purposes, a purposeful sampling method was employed to secure a sufficient number of each student group for meaningful statistical analysis. Our sample comprised 6.3\% non-Chinese South Asian students (NCS) and $6.3 \%$ newly arrived students from Mainland China (NAS) with $87.4 \%$ Mainstream Chinese students as a reference group. In terms of ethnicity, 92.1\% of students were Chinese, 5.4\% were South Asians including Indian, Pakistani, Nepalese, Filipinos, and $2.5 \%$ were others. $7.2 \%$ of students have lived in Hong Kong for less than 3 years. In terms of gender, 55.1\% were male. $49.1 \%$ of the students were at the junior secondary level. Table 1 presents more demographic details of the sample by student groups. 
Table 1. Demographic profile

\begin{tabular}{|c|c|c|c|c|}
\hline & & \multicolumn{3}{|c|}{ Student Group } \\
\hline & & $\begin{array}{c}\text { Mainstream } \\
\text { Chinese }\end{array}$ & NCS & NAS \\
\hline \multirow[t]{7}{*}{ Ethnicity } & Chinese & 4769 (98.1\%) & $0(0.0 \%)$ & $350(99.7 \%)$ \\
\hline & Indian & $0(0.0 \%)$ & $17(4.9 \%)$ & $0(0.0 \%)$ \\
\hline & Pakistani & $0(0.0 \%)$ & $123(35.5 \%)$ & $0(0.0 \%)$ \\
\hline & Nepalese & $0(0.0 \%)$ & $76(22.0 \%)$ & $0(0.0 \%)$ \\
\hline & Filipinos & $0(0.0 \%)$ & $83(24.0 \%)$ & $0(0.0 \%)$ \\
\hline & Indonesian & $0(0.0 \%)$ & $5(1.4 \%)$ & $0(0.0 \%)$ \\
\hline & Others & $94(1.9 \%)$ & $42(12.1 \%)$ & $1(0.3 \%)$ \\
\hline \multirow[t]{2}{*}{ Gender } & Male & $2690(55.6 \%)$ & 117 (51.9\%) & $181(51.9 \%)$ \\
\hline & Female & $2149(44.4 \%)$ & $164(48.1 \%)$ & $168(48.1 \%)$ \\
\hline \multirow[t]{2}{*}{ Level of study } & Junior secondary & $2291(47.1 \%)$ & 197 (56.6\%) & $243(69.0 \%)$ \\
\hline & Senior secondary & $2575(52.9 \%)$ & $151(43.4 \%)$ & $109(31.0 \%)$ \\
\hline \multirow{7}{*}{$\begin{array}{l}\text { Religious } \\
\text { affiliation }\end{array}$} & No & $3282(68.4 \%)$ & $37(10.9 \%)$ & $249(72.0 \%)$ \\
\hline & Christianity & $1141(23.8 \%)$ & $100(29.5 \%)$ & $24(6.9 \%)$ \\
\hline & Islam & $6(0.1 \%)$ & $116(34.2 \%)$ & $1(0.3 \%)$ \\
\hline & Hinduism & $7(0.1 \%)$ & $20(5.9 \%)$ & $1(0.3 \%)$ \\
\hline & Buddhism & $251(5.2 \%)$ & $36(10.6 \%)$ & $59(17.1 \%)$ \\
\hline & Taoism & $32(0.7 \%)$ & $3(0.9 \%)$ & $3(0.9 \%)$ \\
\hline & Others & $76(1.6 \%)$ & $27(8.0 \%)$ & $9(2.6 \%)$ \\
\hline
\end{tabular}

\section{Measures}

School Engagement. The School Engagement Scales developed by Fredericks et al. (2005), and Hart, Stewart and Jimerson (2011) were modified and piloted. Students were asked to evaluate their school engagement affectively, behaviorally and cognitively. The modified School Engagement Scale (SESM) included 20 questions in 6 point Likert scale. Respondents had to indicate their agreement on the questions in affective and cognitive engagement while reporting the participating frequency in the conducts for behavior engagement. Sample questions included: "I feel good at school", 
"When learning new information, I try to put the ideas in my own words", "I pay attention in class". Cronbach's alpha of the scale was 0.941 which suggests a high internal consistency and the CFA results ${ }^{1}$ also suggest a good model fit.

Students' civic-related self-belief. The following three domains of the ICCS student questionnaire (Schulz et al., 2009) were assessed, namely interest in politics and social issues, sense of internal political efficacy, and citizenship self-efficacy. Sample items of the domain interest in politics and social issues include the question: "How interested are you in the following issues?". On the domain of citizenship self-efficacy, items include "discuss a newspaper article about a conflict between countries" and "argue your point of view about a controversial political or social issue". According to the results of $\mathrm{CFA}^{2}$, the 20 items were validated with a good model fit. Reliability for the validated three-indicator model reached 0.936, suggesting good internal consistency.

The Students' Behaviours of Civic Engagement. The three domains of the ICCS student questionnaire (Schulz et al., 2009), namely political discussion, participation in the wider community and at school, were assessed. For political discussion, students were asked to indicate their involvement in "talking with their parents about what is happening in other countries", and "talking with their friends about political and social issues". For participation in the wider community, students' participation with organizations was reported. They had to indicate whether they joined any "environmental organization", "human rights organization" and "religious group" etc. Sample question of school participation included: "At school, have you ever done any of the following activities?". The scale had a Cronbach's alpha (0.888) indicating a high internal consistency. Results of CFA ${ }^{3}$ also indicated that there was a good model fit.

Expected political participation in the future. Both students' expected participation in political protest scale and students' expected political participation scale were selected from the ICCS student questionnaire to measure the expected political participation of students in the future. The two scales comprise five factors: (1) legal protest, (2) illegal protest, (3) electoral participation, (4) political participation, and (5) informal political participation. Sampled items included: "contacting an elected representative", "blocking traffic", "vote in Legislative Council elections", "join a political

\footnotetext{
$\chi^{2}=2018.943, \mathrm{df}=163, \mathrm{p}<0.001, \mathrm{CFI}=0.960, \mathrm{TLI}=0.954, \mathrm{RMSEA}=0.047, \mathrm{SRMR}=0.043$.

$\chi^{2}=1837.3, \mathrm{df}=94, \mathrm{p}<0.001, \mathrm{CFI}=0.991, \mathrm{TLI}=0.988, \mathrm{RMSEA}=0.058, \mathrm{SRMR}=0.023$.

$\chi^{2}=1031.766, \mathrm{df}=113, \mathrm{p}<0.001, \mathrm{CFI}=0.989, \mathrm{TLI}=0.986, \mathrm{RMSEA}=0.040, \mathrm{SRMR}=0.036$.
} 
party", "volunteer time to help people in the local community", etc. The Cronbach's alpha of the former scale was 0.905 and the latter 0.922. The CFA results were $\chi^{2}(10)=103.730, \mathrm{p}<.001, \mathrm{CFI}=.996, \mathrm{TLI}=.993, \mathrm{RMSEA}=.043$, $\mathrm{SRMR}=.009$ and $\chi^{2}(21)=219.035, \mathrm{p}<.001, \mathrm{CFI}=.995, \mathrm{TLI}=.992, \mathrm{RMSEA}=.043$, $\mathrm{SRMR}=.018$ respectively.

\section{FINDINGS}

\section{Student group differences}

Table 2 describes the details of the means and standard deviations of each scale across the three student groups. The results of MANOVA indicated that the student groups were significantly different in the level of school engagement, self-belief and behaviors of civic engagement, and their expected political participation in the future. The differences in school engagement across the student groups were found significant. ${ }^{4}$ Specifically, NCS was identified to have scored the highest level of affective and cognitive engagement with school when compared with both mainstream Chinese and NAS. In the behavioral domain, NCS was only significantly higher than the mainstream Chinese, but not NAS. In terms of school engagement, however, there was no statistical significance between the two Chinese student groups.

Significant student group differences were detected in students' civicrelated self-belief. ${ }^{5}$ By contrast, no significant group difference was identified regarding students' interest in political issues. It is noteworthy that the highest scores of internal political efficacy and citizenship self-efficacy were found among the NCS. Similar results were yielded in both the Hong Kong mainstream Chinese and NAS in these two areas.

There were significant student group differences in students' behaviours related to civic engagement. ${ }^{6}$ Consistent with the above student group results, NCS reported a high level of civic engagement outside school and political discussion. As for the mainstream Chinese and NAS, no significant difference was found across the three assessed areas.

Student's expected political participation in the future was also investigated. Significant student group differences were identified in (1) participation in political protest scale ${ }^{7}$ and (2) students' expected political participa-

\footnotetext{
$\mathrm{F}(2)=11.239, \mathrm{p}<.001$, Wilks' $\Lambda=.987$, partial $\eta^{2}=.007$.

$\mathrm{F}(2)=3.778, \mathrm{p}<.05$, Wilks' $\Lambda=.996$, partial $\eta^{2}=.002$.

$\mathrm{F}(2)=26.472, \mathrm{p}<.001$, Wilks' $\Lambda=.968$, partial $\eta^{2}=.016$.

$\mathrm{F}(2)=34.377, \mathrm{p}<.001$, Wilks' $\Lambda=.976$, partial $\eta^{2}=.013$.
} 
tion scale ${ }^{8}$. The findings of post hoc tests further showed that NAS gave the lowest scores to the two factors: legal protest and electoral participation. By contrast, NCS scored highest in participating in illegal protest and political participation and informal political participation as compared with their mainstream Chinese and NAS counterparts.

Table 2. Results of MANOVA by student groups

\begin{tabular}{|c|c|c|c|c|}
\hline & & \multicolumn{3}{|c|}{ Student group } \\
\hline & & $\begin{array}{l}\text { Mainstream } \\
\text { Chinese }\end{array}$ & NCS & NAS \\
\hline \multirow{4}{*}{$\begin{array}{l}\text { School } \\
\text { engagement }\end{array}$} & Affective & $4.27(.98)$ & $4.60(1.20)$ & $4.16(1.03)$ \\
\hline & Behavioral & $4.09(.93)$ & $4.32(1.12)$ & $4.18(.93)$ \\
\hline & Cognitive & $4.23(.88)$ & $4.56(1.09)$ & $4.11(.94)$ \\
\hline & \multicolumn{4}{|c|}{$\mathrm{F}(2)=11.239, \mathrm{p}<.001$, Wilks $\Lambda=.987$, partial $\eta^{2}=.007$} \\
\hline \multirow[t]{4}{*}{$\begin{array}{l}\text { Civic-related } \\
\text { self-belief }\end{array}$} & $\begin{array}{l}\text { Interest is political and } \\
\text { social issues }\end{array}$ & $2.43(.71)$ & $2.47(.79)$ & $2.43(.73)$ \\
\hline & Internal political efficacy & $2.30(.66)$ & $2.43(.77)$ & $2.26(.64)$ \\
\hline & Citizenship self-efficacy & $2.31(.75)$ & $2.46(.81)$ & $2.31(.76)$ \\
\hline & \multicolumn{4}{|c|}{$\mathrm{F}(2)=3.778, \mathrm{p}<.05$, Wilks' $\Lambda=.996$, partial $\eta^{2}=.002$} \\
\hline \multirow{4}{*}{$\begin{array}{l}\text { Behaviours } \\
\text { of civic } \\
\text { engagement }\end{array}$} & Political discussion & $2.18(.80)$ & $2.52(.82)$ & $2.00(.82)$ \\
\hline & $\begin{array}{l}\text { Participation in the wider } \\
\text { community }\end{array}$ & $1.31(.42)$ & $1.62(.57)$ & $1.29(.43)$ \\
\hline & Participation in school & $1.62(.53)$ & $1.81(.59)$ & $1.56(.50)$ \\
\hline & \multicolumn{4}{|c|}{$\mathrm{F}(2)=26.472, \mathrm{p}<.001$, Wilks $\Lambda=.968$, partial $\eta^{2}=.016$} \\
\hline \multirow{7}{*}{$\begin{array}{l}\text { Expected } \\
\text { political } \\
\text { participation } \\
\text { in future }\end{array}$} & Legal protest & $2.30(.80)$ & $2.39(.83)$ & $2.14(.76)$ \\
\hline & Illegal protest & $1.78(.81)$ & $2.27(.92)$ & $1.79(.79)$ \\
\hline & \multicolumn{4}{|c|}{$\mathrm{F}(2)=34.377, \mathrm{p}<.001$, Wilks $\Lambda=.976$, partial $\eta^{2}=.013$} \\
\hline & Electoral participation & $2.55(.93)$ & $2.46(.90)$ & $2.23(.86)$ \\
\hline & Political participation & $1.87(.81)$ & $2.26(.90)$ & $1.86(.78)$ \\
\hline & $\begin{array}{l}\text { Informal political } \\
\text { participation }\end{array}$ & $2.40(.76)$ & $2.49(.82)$ & $2.33(.75)$ \\
\hline & \multicolumn{4}{|c|}{$\mathrm{F}(2)=25.488, \mathrm{p}<.001$, Wilks $\Lambda=.971$, partial $\eta^{2}=.015$} \\
\hline
\end{tabular}

$8 \quad \mathrm{~F}(2)=25.488, \mathrm{p}<.001$, Wilks' $\Lambda=.971$, partial $\eta^{2}=.015$. 


\section{Effects of school engagement on expected political participation in the future}

Table 3 presents the results of hierarchical regressions and confirmed that school engagement was significant in predicting the likelihood of participating in both legal protest and illegal protest in the future. Specifically, in legal protest, affective engagement $[\beta=.049, \mathrm{t}(4322)=2.495, \mathrm{p}<.05]$, behavioral engagement $[\beta=.116, t(4322)=6.389, p<.001]$ and cognitive engagement $[\beta=.171, \mathrm{t}(4322)=8.277, \mathrm{p}<.001]$ were significant with an explanatory power of $\mathrm{R}^{2}=.084, \mathrm{~F}(3,4322)=132.515, \mathrm{p}<.001$. Considering illegal protest, both behavioral engagement $[\beta=.050, t(4455)=2.681, p<.01]$ and cognitive engagement $[\beta=.150, t(4269)=7.233, \mathrm{p}<.001]$ were significant predictive factors with an explanatory power of $\mathrm{R}^{2}=.028, \mathrm{~F}(3,4269)=41.805$, $\mathrm{p}<.001$.

Taking a closer look of the regression results, it was found that school engagement was also significant in predicting the likelihood of student participation in the following activities: electoral participation $\left[\mathrm{R}^{2}=101, \mathrm{~F}(3\right.$, $4322)=162.733, \mathrm{p}<.001]$, political participation $\left[\mathrm{R}^{2}=.058, \mathrm{~F}(3,4323)=87.240\right.$, $\mathrm{p}<.001]$ and informal political participation $\left[\mathrm{R}^{2}=.138, \mathrm{~F}(3,4325)=232.223\right.$, $\mathrm{p}<.001]$. The findings showed that affective engagement was significant in explaining electoral participation $[\beta=.097, \mathrm{t}(4322)=4.946, \mathrm{p}<.001]$ and informal political participation $[\beta=.093, \mathrm{t}(4325)=4.851, \mathrm{p}<.001]$. Behavioral engagement was a significant predictor for the following factors: electoral participation $[\beta=.124, \mathrm{t}(4322)=6.899, \mathrm{p}<.001]$, political participation $[\beta=.090, \mathrm{t}(4232)=4.858, \mathrm{p}<.001]$ and informal political participation $[\beta=.162$, $t(4325)=9.182, p<.001]$. On the other side, cognitive engagement was also significant predictor of same constructs: electoral participation $[\beta=.154$, $\mathrm{t}(4322)=7.759, \mathrm{p}<.001]$, political participation $[\beta=.159, \mathrm{t}(4232)=7.724, \mathrm{p}<.001]$ and informal political participation $[\beta=.183, \mathrm{t}(4325)=9.455, \mathrm{p}<.001]$. 
Table 3. Regressions of school and civic engagement with students' expected political participation in future

\begin{tabular}{|c|c|c|c|c|c|}
\hline & $\begin{array}{l}\text { Legal } \\
\text { Protest }\end{array}$ & $\begin{array}{l}\text { Illegal } \\
\text { Protest }\end{array}$ & $\begin{array}{l}\text { Electoral } \\
\text { Participation }\end{array}$ & $\begin{array}{l}\text { Political } \\
\text { Participation }\end{array}$ & $\begin{array}{l}\text { Informal } \\
\text { Political } \\
\text { Participation }\end{array}$ \\
\hline Affective & $.049^{* *}$ & & $.097^{* * *}$ & & $.093^{* * *}$ \\
\hline Behavioral & $.116^{* * *}$ & $.046^{* *}$ & $.124^{* * *}$ & $.090^{* * *}$ & $.162^{* * *}$ \\
\hline Cognitive & $.171^{* * *}$ & $.150^{* * *}$ & $.154^{* * *}$ & $.159^{* * *}$ & $.183^{* * *}$ \\
\hline Adjusted R square & 0.084 & 0.028 & 0.101 & 0.058 & 0.138 \\
\hline $\begin{array}{l}\text { Interest in political } \\
\text { and social issues }\end{array}$ & $.149^{* * *}$ & & $.237^{* * *}$ & & $.219^{* * *}$ \\
\hline $\begin{array}{l}\text { Internal political } \\
\text { efficacy }\end{array}$ & $.143^{* * *}$ & $.135^{* * *}$ & $.183^{* * *}$ & $.186^{* * *}$ & $.154^{* * *}$ \\
\hline $\begin{array}{l}\text { Citizenship self- } \\
\text { efficacy }\end{array}$ & $.187^{* * *}$ & $.273^{* * *}$ & $.097^{* * *}$ & $.298^{* * *}$ & $.188^{* *}$ \\
\hline R square changed & 0.135 & 0.110 & 0.165 & 0.172 & 0.186 \\
\hline Political discussion & $.115^{* * *}$ & $.059^{* *}$ & $.121^{* * *}$ & $.078^{* * *}$ & $.146^{* * *}$ \\
\hline $\begin{array}{l}\text { Participation in } \\
\text { wider community }\end{array}$ & $.139^{* * *}$ & $.261^{* * *}$ & & $.201^{* * *}$ & $.091^{* * *}$ \\
\hline $\begin{array}{l}\text { Participation at } \\
\text { school }\end{array}$ & $.151^{* * *}$ & $.054^{* *}$ & $0.140^{* * *}$ & $.072^{* * *}$ & $.143^{* * *}$ \\
\hline R square changed & 0.061 & 0.072 & 0.027 & 0.054 & 0.051 \\
\hline
\end{tabular}

\section{Effects of civic engagement on expected political participation in future}

Also shown in Table 3, the three factors measuring students' civic-related self-belief were added into the above analysis as Model 2 in the hierarchical regression. The result indicated that students' civic-related self-belief was significant in predicting participation of both legal and illegal protest in the future. Students' interest in political and social issues was only significant at predicting legal protest $[\beta=.149, \mathrm{t}(4319)=7.883, \mathrm{p}<.001]$. Both legal and illegal protest were predicted by internal political efficacy [legal protest: $\beta=.143$, 
$\mathrm{t}(4319)=6.758, \mathrm{p}<.001$; illegal protest: $\beta=.135, \mathrm{t}(4266)=6.023, \mathrm{p}<.001]$ and citizenship efficacy [legal protest: $\beta=.257, \mathrm{t}(4319)=16.885, \mathrm{p}<.001$; illegal protest: $\beta=.273, \mathrm{t}(4266)=14.284, \mathrm{p}<.001]$ with explanatory power substantially increased as opposed to Model 1, i.e., $\Delta \mathrm{R}^{2}=.135, \mathrm{~F}(3,4319)=132.515, \mathrm{p}<.001$ and $\Delta \mathrm{R}^{2}=.110, \mathrm{~F}(3,4266)=182.148, \mathrm{p}<.001$, respectively.

The three factors measuring students' behaviors in civic engagement were entered as Model 3 in the hierarchical regressions. The result revealed that all the three factors were significant predictors: political discussion [legal protest: $\beta=.115, \mathrm{t}(4316)=6.720, \mathrm{p}<.001$; illegal protest: $\beta=.059$, $\mathrm{t}(4263)=3.253, \mathrm{p}<.05$ ], participation in the wider community [legal protest: $\beta=.139, \mathrm{t}(4316)=8.768, \mathrm{p}<.001$; illegal protest: $\beta=.261, \mathrm{t}(4263)=15.565, \mathrm{p}<.001]$, and participation at school [legal protest: $\beta=.151, \mathrm{t}(4316)=9.188, \mathrm{p}<.001$; illegal protest: $\beta=.054, \mathrm{t}(4263)=3.128, \mathrm{p}<.05]$. The explanatory power increased to a lesser extent, i.e., $\Delta R^{2}=.061, F(3,4316)=123.042$, $\mathrm{p}<.001$ and $\Delta \mathrm{R}^{2}=.072, \mathrm{~F}(3$, 4263) $=130.424, \mathrm{p}<.001$, respectively.

When considering the expected electoral, political and informal participation, all of them were significantly predictable by both students' civicrelated self-belief and behaviors. Large $\mathrm{R}$ square changes were in evidence when the three self-belief factors were entered in Model 2 in the hierarchical regression [electoral participation: $\Delta \mathrm{R}^{2}=.165, \mathrm{~F}(3,4319)=325.024, \mathrm{p}<.001$; political participation: $\Delta \mathrm{R}^{2}=.172, \mathrm{~F}(3,4229)=314.470$, $\mathrm{p}<.001$; informal political participation: $\Delta \mathrm{R}^{2}=.186, \mathrm{~F}(3,4322)=396.926$, $\left.\mathrm{p}<.001\right]$. Internal political efficacy and citizenship efficacy significantly affected all the three aspects of students' future political participation. Although it was not a significant predictor of (formal) political participation, students' interest in political and social issues was the strongest predictor of their electoral and informal political participation [electoral participation: $\beta=.237, \mathrm{t}(4319)=12.958$, $\mathrm{p}<.001$; informal political participation: $\beta=.219, \mathrm{t}(4322)=12.453, \mathrm{p}<.001]$.

The three civic behaviors factors led to much smaller $\mathrm{R}$ square changes when entered in Model $3^{9}$, which were even smaller than the proportions of variances the school engagement factors explained. Political discussion explained electoral participation, political participation and informal political participation ${ }^{10}$ respectively. Participation in the wider community was significant in predicting political participation $[\beta=.201, \mathrm{t}(4226)=12.495, \mathrm{p}<.001]$

9 Electoral participation: $\Delta \mathrm{R}^{2}=.027, \mathrm{~F}(3,4316)=55.216, \mathrm{p}<.001$; political participation: $\Delta \mathrm{R}^{2}=.054$, $\mathrm{F}(3,4226)=106.981, \mathrm{p}<.001$; informal political participation: $\Delta \mathrm{R}^{2}=.051, \mathrm{~F}(3,4319)=116.711$, $\mathrm{p}<.001$.

${ }_{10} \beta=.121, \mathrm{t}(4316)=7.141, \mathrm{p}<.001, \beta=.078, \mathrm{t}(4226)=4.497, \mathrm{p}<.001$ and $\beta=.146, \mathrm{t}(4319)=9.111$, $\mathrm{p}<.001$. 
and informal political participation $[\beta=.091, \mathrm{t}(4319)=6.104, \mathrm{p}<.001]$ but not electoral participation. Participation at school was a significant predictor of all the three aspects of expected political participation in the future, explaining power of which was close to political discussion.

In brief, students' civic engagement was distinctly more influential to their future political participation than school engagement. Self-belief related to civic issues explained the largest proportions of variance, ranging from as high as $11 \%$ to $18.6 \%$. Their behaviors on civic engagement $(7.2 \%)$ were more influential on illegal protest as compared to school engagement $(2.8 \%)$. While students school engagement accounted for considerably large proportions of variance on electoral participation (10.1\%) and informal political participation (13.8\%).

\section{Effects of school and civic engagement on expected political participation in future by student groups}

In order to examine the effects of student engagement with school and civic society on their perceived future civic participation across the three student groups, hierarchical regression was performed. Table 4a presents the results for mainstream Chinese students. Both the behavioral and cognitive domains of school engagement were significant predictors for their future civic participation and the cognitive domain accounts more for the effects. In addition, while the predicting power of school engagement was lowest on illegal protest $(2.4 \%)$ and political participation $(5.2 \%)$ and the strongest on informal political participation (13.9\%) and electoral participation $(10.2 \%)$.

With regard to self-assessed civic engagement, both internal political efficacy and citizenship self-efficacy contributed significantly to their future political participation across all the domains. In addition, their involvement in political discussion and participation in school had significant effects on all the domains. Participation in the wider community was distinctly influential on illegal protest and political participation but showed no effect on electoral participation at all. In brief, civic-related self-belief was most influential on expected political protest and participation, accounting for 11.8\% to $18.5 \%$ of the total variance, behaviors of civic engagement being the least influential. On the whole, civic engagement affected students' future political participation more than school engagement. 
Table 4a. Regressions of school and civic engagement on students' expected political participation in future by student group (HK mainstream)

\begin{tabular}{|c|c|c|c|c|c|}
\hline & $\begin{array}{l}\text { Legal } \\
\text { Protest }\end{array}$ & $\begin{array}{l}\text { Illegal } \\
\text { Protest }\end{array}$ & $\begin{array}{l}\text { Electoral } \\
\text { Participation }\end{array}$ & $\begin{array}{l}\text { Political } \\
\text { Participation }\end{array}$ & $\begin{array}{l}\text { Informal } \\
\text { Political } \\
\text { Participation }\end{array}$ \\
\hline Affective & $.048^{* *}$ & & $.089^{* * *}$ & & $.090^{* * *}$ \\
\hline Behavioral & $.110^{* * *}$ & & $.124^{* * *}$ & $.075^{* * *}$ & $.157^{* * *}$ \\
\hline Cognitive & $.177^{* * *}$ & $.150^{* * *}$ & $.165^{* * *}$ & $.164^{* * *}$ & $.193^{* * *}$ \\
\hline Adjusted R square & 0.082 & 0.024 & 0.102 & 0.052 & 0.139 \\
\hline $\begin{array}{l}\text { Interest in political } \\
\text { and social issues }\end{array}$ & $.158^{* * *}$ & & $.234^{* * *}$ & & $.212^{* * *}$ \\
\hline $\begin{array}{l}\text { Internal political } \\
\text { efficacy }\end{array}$ & $.160^{* * *}$ & $.146^{* * *}$ & $.203^{* * *}$ & $.190^{* * *}$ & $.173^{* * *}$ \\
\hline $\begin{array}{l}\text { Citizenship self- } \\
\text { efficacy }\end{array}$ & $.175^{* * *}$ & $.271^{* * *}$ & $.085^{\star * *}$ & $.296^{* * *}$ & $.172^{* * *}$ \\
\hline$R$ square changed & 0.144 & 0.118 & 0.172 & 0.172 & 0.185 \\
\hline Political discussion & $.123^{* * *}$ & $.048^{* *}$ & $.123^{* * *}$ & $.076^{* * *}$ & $.140^{* * *}$ \\
\hline $\begin{array}{l}\text { Participation in } \\
\text { wider community }\end{array}$ & $.147^{* * *}$ & $.249^{* * *}$ & & $.190^{* * *}$ & $.090^{* * *}$ \\
\hline $\begin{array}{l}\text { Participation at } \\
\text { school }\end{array}$ & $.153^{* * *}$ & $.058^{* *}$ & $0.137^{* * *}$ & $.070^{* * *}$ & $.147^{* * *}$ \\
\hline R square changed & 0.067 & 0.067 & 0.028 & 0.050 & 0.051 \\
\hline
\end{tabular}

Table $4 \mathrm{~b}$ presents the results of NCS and shows that behavioural engagement is the only predictor for their future civic participation except for illegal protest. The results indicated that the explanatory power of school engagement was largest on electoral participation (16.3\%) and smallest on political participation (8.3\%). In terms of civic engagement, citizenship selfefficacy was the dominating predictor and participation in the wider community was also found significant with regard to their future civic participation. Civic-related self-belief made the biggest difference on formal and 
informal political participation, and behaviors on civic engagement affected illegal protest the most, and school engagement affected legal protest $(9.8 \%)$ and electoral participation (16.3\%) the most among the three scales. In contrast with the limited explaining power of political discussion, participation at school was not predictive on the whole range of expected political participation.

Table 4b. Regressions of school and civic engagement on students' expected political participation in future by student group (NCS)

$$
\begin{array}{lllll}
\text { Legal } & \text { Illegal } & \text { Electoral } & \text { Political } & \text { Informal } \\
\text { Protest } & \text { Protest } & \text { Participation } & \text { Participation } & \text { Political } \\
& & & & \text { Participation }
\end{array}
$$

Affective

Behavioral $.194^{* *} \quad .334^{* *} \quad .285^{* *} \quad .312^{* *}$

Cognitive

$\begin{array}{llllll}\text { Adjusted R square } & 0.098 & 0.029 & 0.163 & 0.083 & 0.134\end{array}$

\begin{tabular}{|c|c|c|c|c|c|}
\hline $\begin{array}{l}\text { Interest in political } \\
\text { and social issues }\end{array}$ & & & & & $.218^{* *}$ \\
\hline $\begin{array}{l}\text { Internal political } \\
\text { efficacy }\end{array}$ & & & & $.213^{* *}$ & \\
\hline $\begin{array}{l}\text { Citizenship self- } \\
\text { efficacy }\end{array}$ & $.218^{* *}$ & $.255^{* * *}$ & $.244^{* * *}$ & $.257^{* *}$ & $.373^{* * *}$ \\
\hline R square changed & 0.058 & 0.056 & 0.107 & 0.170 & 0.217 \\
\hline Political discussion & & & & & $.184^{* *}$ \\
\hline $\begin{array}{l}\text { Participation in } \\
\text { wider community }\end{array}$ & $.259^{* *}$ & $.405^{* * *}$ & & $.304^{* * *}$ & $.213^{* *}$ \\
\hline \multicolumn{6}{|l|}{$\begin{array}{l}\text { Participation at } \\
\text { school }\end{array}$} \\
\hline R square changed & 0.059 & 0.118 & 0.029 & 0.078 & 0.079 \\
\hline
\end{tabular}


Table 4c presents the results of NAS and finds that cognitive engagement was a strong predictor for students' expected political participation in the future, followed by behavioural engagement. However, affective engagement was not significant in predicting their expected political participation in the future. The findings suggested that the electoral participation could not be explained by school engagement. On the other hand, the self-assessed civic participation of NAS showed political discussion and participation in the wider community were significant predictors for their future civic participation. Civic-related self-belief, particularly citizenship self-efficacy, was most influential on expected political protest and participation, accounting for $7.7 \%$ to $18 \%$ of the total variance, while internal political efficacy had no predicting power. Political discussion and participation in the wider community jointly added $5.8 \%$ of the explaining power.

Table 4c. Regressions of school and civic engagement on students' expected political participation in future by student group (NAS)

$$
\begin{array}{lllll}
\text { Legal } & \text { Illegal } & \text { Electoral } & \text { Political } & \text { Informal } \\
\text { Protest } & \text { Protest } & \text { Participation } & \text { Participation } & \text { Political } \\
& & & & \text { Participation }
\end{array}
$$

\begin{tabular}{llllll} 
Affective & & & & \\
Behavioral & $.177^{* *}$ & $.176^{* *}$ & & $.165^{* *}$ & $.141^{* *}$ \\
Cognitive & $.159^{* *}$ & $.182^{* *}$ & & $.175^{* *}$ & $.184^{* *}$ \\
Adjusted R square & 0.066 & 0.051 & 0.059 & 0.065 & 0.118 \\
\hline $\begin{array}{l}\text { Interest in political } \\
\text { and social issues }\end{array}$ & & $.288^{* * *}$ & & $.272^{* * *}$ \\
$\begin{array}{l}\text { Internal political } \\
\text { efficacy }\end{array}$ & & & & & \\
$\begin{array}{l}\text { Citizenship self- } \\
\text { efficacy }\end{array}$ & $.353^{* * *}$ & $.303^{* * *}$ & $.201^{* *}$ & $.363^{* * *}$ & $.264^{* * *}$ \\
$\begin{array}{l}\text { R square changed } \\
0.128\end{array}$ & 0.077 & 0.160 & 0.175 & 0.180 \\
\hline $\begin{array}{l}\text { Political discussion } \\
\text { Participation in } \\
\text { wider community }\end{array}$ & & $.173^{* *}$ & & & $.191^{* *}$
\end{tabular}




\section{Legal Illegal Electoral Political Informal \\ Protest Protest Participation Participation Political \\ Participation}

Participation at

school
$0.149^{* *}$

$.147^{* *}$
R square changed $\quad 0.027$
0.058
0.030
0.049
0.036

Compared to students' school engagement, civic engagement affected their expected political participation to a considerably larger extent. For mainstream Chinese students and NAS, civic-related self-belief was most influential to expected political protest and participation, ranging from $11.8 \%$ to $18.5 \%$ and from $7.7 \%$ to $18 \%$, respectively. For NCS civic-related self-belief made the biggest difference in formal and informal political participation, and behaviors in civic engagement affected illegal protest the most, while school engagement affected legal protest and electoral participation the most. Compared to school engagement, civic engagement affected expected political participation to a considerably larger extent, which is true for all three student groups. Further, students' citizenship self-efficacy was most influential among the school and civic engagement domains, and the affective domain of school engagement had little effects.

\section{DISCUSSION AND CONCLUSION}

Founded on the frameworks of student engagement, this study aims to provide insights into the school and civic engagement of culturally diverse students in an Asian context, in Hong Kong. Consistent with other studies (Torney-Purta, 2002; Syvertsen, Flanagan and Stout, 2007) this study confirms that student engagement with school and civic society predicted their civic participation in the future. For example, our hierarchical regressions on civic related self-belief, particularly on citizenship self-efficacy revealed that it was the most predicting factor for future civic participation. Put simply, expressed interests of students in activities such as voicing out personal opinions and/or standpoint about a political or social issue, organizing class debates, and writing a letter to an editor arguing about a controversial political or social issue, will have direct implications for their future civic outcomes. School is an ideal place to promote civic education and to examine the way in which intended civic outcomes are achieved, or not. 
Patterns of student engagements across the mainstream Chinese, NCS and NAS have been identified. The significant differences between NCS and NAS, and mainstream Chinese students at/in school engagement indicated that the differences were due to reasons other than random errors. In contrast to some of the earlier studies conducted in the United States that immigrant youth are generally less engaged in civic matters (Torney-Purta, 2002; Lopez and Marcelo, 2008), our findings have proved that NCS were the most engaged group with school affectively and cognitively. This finding is contrary to conventional and even intuitive understanding. However, their relatively affirmative response was corroborated with related studies on their life satisfaction (Yuen, 2013; Yuen and Lee, 2013). These students are predominantly from the underprivileged sector, mainly from South Asian families, namely Nepalese, Pakistani, Indians and Filipinos. Typically, their fathers are the sole bread winner and are employed in the construction, security and catering sectors, while their mothers are mostly fulltime home makers. The lack of spoken Cantonese is their biggest barrier in making effective community networks (Yuen, 2013). Despite the fact that they have less social capital, these young South Asians have consistently expressed a rather optimistic view of their school bonding and attachments, especially compared with the local mainstream Chinese. One reason is to be found in their positive world view, which focuses on more relational issues than personal success. Rewarding friendships with their ethnic peers has been successfully cultivated and promoted. Another reason is due to the characteristics of the participating schools: most of the sampled NCS were educated in designated schools with high concentrations of ethnic minority students, which receive extra funding from the government for the initiation of school-based policies (Yuen and Lee, 2013). Additional and/or tailormade learning support was provided by these schools to improve the environment for non-local South Asian students. One of the effective measures was providing support towards building their social networks at school and establishing good relationships with their significant others, teachers and peers (Skinner and Belmount, 1993; Elmore and Huebner, 2010).

Likewise, in term of civic engagement, NCS were also very keen in civic activities including holding political discussion with friends and parents, and participating in future illegal protest (blocking traffic, occupying public buildings), joining political organizations and/or parties (standing as a candidate for district council elections). Again, these findings are unique to this sample and differ from conventional understanding of immigrant adolescents in the receiving society (Torney-Purta, 2002). To readers from 
a civil society with a history of democracy, the above-mentioned activities may well be perceived as normal practice. They are, nevertheless, perceived as rather radical social actions in an Asian society, even in Hong Kong. On the one hand, this reveals the hidden voices of ethnic minorities about their new society and their aspirations for greater social integration, recognition and self-actualization. On the other, we speculate that these findings reflect their dissatisfaction with the existing social and political situations and/or the lack of channels for their voices. Much is to be told, hence, it is imperative to conduct further investigation on their opinions about the current political system. With regard to public policy, this shows there is a need for a re-examination of the root causes of their desire to support such social actions in order for them to realize their civic goals, and to build a more democratic society for all.

With the two Chinese student groups, domain differences were found in school and civic engagement. Local mainstream Chinese students gave a higher score to their future civic participation in legal protest and electoral participation than NAS. By contrast, NAS suggested a higher score in behavioral engagement in school.

The research indicates that minority and immigrant adolescents and their parents are involved more at a community level, though not at the political level (Jensen, 2008). With regard to civic engagement, our findings show that the NCS in Hong Kong are mostly second-generation immigrants whose parents have a closer relationship with their home countries and are more likely to initiate discussion on policies and politics. Though their parents might not concentrate on their children's academic performance as much as the local parents (Yuen and Lee, 2013), nevertheless, as a disadvantaged and under privileged group, NCS might prove eager to make changes for a better life through their own civic involvement and diligence, especially with the assistance of government and non-governmental organizations. By contrast, NAS were found socially withdrawn and less engaged, which echoes some previous findings on the issues of social exclusion and isolation of immigrant students (Yuen, 2009).

Despite having a smaller impact on students' future political participation as against civic engagement, students' school engagement does make a difference. From affective, behavioral and cognitive perspectives, positive school engagement raises the likelihood of students' future electoral and informal participation by over $10 \%$ (explained over $10 \%$ of the total variances). One reason for this could be that political participation is linked with personal exposure and life experiences at school, while school was 
the platform/avenue for the civic events. On the one hand, schools often organized informal and non-political activities, such as, voluntary work (AYP - HK Award for Young People), to broaden students view and cultivate their recognition of social events. Extra-curricular activities provide eye-opening opportunities for local students to be in touch with the wider social learning environment and be inspired by the people and issues they encountered. On the other hand, students who were more cognitively and behaviorally engaged in schools were usually the top individuals, serving as student leaders/prefects/society committee members in the school environment. Hence, they were relatively more familiar with committee work and serving as a bridge between school management and fellow students. These roles equip them with the necessary skills, awareness and knowledge for political activities in the future.

It was not surprising that students who were active in political discussion and participated in community events were more likely to maintain their enthusiasm towards social and political occurrences in the future. In contrast with the general trend for the large majority of adolescents in Hong Kong, although NCS have more political discussion with their parents and friends about their home countries, this discussion may not lead to their engagement/participation in political activities in the future.

Despite this, the active participation of NCS students in community activities overshadowed their purely political discussions, and manifested a larger possibility for them to be more active in political participation than their counterparts in the future. It was worth noting that for this group, actions, rather than mental activities like cognition and discussion, were more predictive of their future actions in political events.

The NCS students consistently scored significantly higher than Chinese Mainstream and NAS students in engagement at school and in civic society, and expected future political protest and participation. Further, Chinese Mainstream students reported higher levels of self-perceptions in this regard than the NAS. In contrast with school engagement, students' civic engagement had a larger impact on their participation in political events. Across the mainstream, NCS and NAS, students' civic-related self-belief in terms of citizenship self-efficacy was most influential with regard to their expected political participation. A sense of internal political efficacy was equally important to the mainstream students. To the NCS and NAS, affections at school engagement did not have any effects on future civic participation. It is therefore recommended that policy makers and educational practitioners should identify particular problems and take appropriate ini- 
tiatives to enable minority/new immigrant and local students to develop greater school and civic participation towards a more inclusive and equal society.

Acknowledgement: This paper is one of the outputs of a Public Policy Research project titled "Engagement of immigrant and minority students with schools and civil society", funded by the University Grant Council, Hong Kong (2012 - 2014). The author would like to acknowledge the generous financial support of the UGC.

\section{REFERENCES}

Adler, R. and Goggin, J. (2005). What Do We Mean By "Civic Engagement", Journal of Transformative Education, 3 (3): 236-253, doi: 10.1177/1541344605276792.

Appleton, J., Christenson, S. and Furlong, M. (2008). Student engagement with school: Critical conceptual and methodological issues of the construct, Psychology in the Schools, 45 (5): 369-386, doi: 10.1002/pits.20303.

Bauhinia Foundation Research Center (2009). [Hong Kong-Shenzhen Education Cooperation], http://www.bauhinia.org/pdf/research/20090407/tchi_HK-SZ_ EducationCooperation_MaiMainRep.pdf (06. 05. 2011).

Diller, E. C. (2001). Citizens in service: The challenge of delivering civic engagement training to national service programs. Washington, DC: Corporation for National and Community Service.

Drummond, K. V. and Stipek, D. (2004). Low-income parents' beliefs about their role in children's academic learning, The Elementary School Journal, 104 (3): 197-213, doi: 10.1086/499749.

Eccles, J. S. and Barber, B. L. (1999). Student council, volunteering, basketball, or marching band: What kind of extracurricular involvement matters?, Journal of Adolescent Research, 14 (1): 10-43, doi: 10.1177/0743558499141003.

Education Bureau (2010). Briefon education support measures for non-Chinese speaking (NCS) students, $\quad$ http://www.edb.gov.hk/attachment/en/student-parents/ncs-students/ about-ncs-students/brief\%20on\%20support\%20measures_english.pdf (10. 06. 2012).

Elmore, G. M. and Huebner, E. S. (2010). Adolescents' satisfaction with school experiences: Relationships with demographics, attachment relationships, and school engagement behavior, Psychology in the Schools, 47 (6): 525-537, doi: 10.1002/pits.20488.

Eng, L. A. (1995). Meanings of multiethnicity: a case study of ethnicity and ethnic relations in Singapore. Oxford: Oxford University Press.

Equal Opportunities Commission (2011). Education for all: Report of the Working Group on Education for Ethnic Minorities. Hong Kong, http://www.eoc.org.hk/eoc/Upload/ UserFiles/File/EducationReportE.pdf (20. 06. 2012). 
Fan, X. (2001). Parental involvement and students' academic achievement: a growth modeling analysis, The Journal of Experimental Education, 70 (1): 27-61, doi: 10.1080/00220970109599497.

Fan, X. and Chen, M. (2001). Parental involvement and students' academic achievement: a meta-analysis, Educational Psychology Review, 13 (1): 1-22.

Finn, J. D. (1989). Withdrawing from school, Review of Educational Research, 59 (2): 117142, doi: 10.3102/00346543059002117.

Finn, J. D. (1993). School engagement and students at risk. Washington: National Centre for Education Statistics.

Fredricks, J. A., Blumenfeld, P. and Paris, A. (2004). School engagement: Potential of the concept, state of the evidence, Review of Educational Research, 74 (1): 59-109, doi: 10.3102/00346543074001059.

Fredricks, J. A., Blumenfeld, P., Friedel, J. and Paris, A. (2005). School engagement, in: K. A. Moore and L. Lippman (eds). What do children need to flourish?: Conceptualizing and measuring indicators of positive development. New York: Springer Science and Business Media, 305-321, doi: 10.1007/0-387-23823-9_19.

Hart, D. and Kirshner, B. (2009). Promoting civic participation and development among urban adolescent, in: J. Youniss and P. Levine (eds). Constructive policy for youth civic engagement. Nashville: Vanderbilt University Press, 102-120.

Hart, S., Stewart, K. and Jimerson, S. (2011). The student engagement in schools questionnaire (SESQ) and the teacher engagement report form - new (TERF-N): Examining the preliminary evidence, Contemporary School Psychology, 15 (1): 67-79.

Hess, D. (2009). Principles that promote discussion of controversial political issues in the curriculum, in: J. Youniss and P. Levine (eds). Engaging young people in civic life. Nashville: Vanderbilt University Press, 59-77.

Hong Kong Unison (2011a). Education for ethnic minorities in Hong Kong: Paper submitted to the Equal Opportunities Commission by Hong Kong Unison. Hong Kong: Hong Kong Unison.

Hong Kong Unison (2011b). Comments on Education Bureau's support measures for NonChinese Speaking Students. Hong Kong: Hong Kong Unison.

Hong, S. H. and Ho, H. Z. (2005). Direct and indirect longitudinal effects of parental involvement on student achievement: second-order latent growth modeling across ethnic groups, Journal of Educational Psychology, 97 (1): 32-42, doi: 10.1037/00220663.97.1.32

Jensen, L. A. (2008). Immigrants' cultural identities as sources of civic engagement, Applied Development Science, 12 (2): 74-83, doi: 10.1080/10888690801997069.

Jimerson, S. R., Campos, E. and Greif, J. L. (2003). Toward an understanding of definitions and measures of school engagement and related terms, The California School Psychologist, 8: 7-27, doi: 10.1007/BF03340893.

Ku, H. B., Chan, K. W. and Sandhu, K. K. (2005). A research report on the education of South Asian ethnic minority groups in Hong Kong. Hong Kong: Centre for Social Policy Studies, Department of Applied Social Sciences, The Hong Kong Polytechnic University - Hong Kong Unison.

Lansdown, G. (2010). The realization of children's participation rights, in: B. Percy-Smith and N. Thomas (eds). Handbook of children and young people's participation. London: Routledge, 11-23. 
Lee, C. M. (2013). [Serving the ethnic minorities means providing good social service] (in Chinese), Kung Kao Po, 4 August, section 20.

Levine, P. and Youniss, J. (eds) (2006). Youth civic engagement: an institutional turn, http:// www.civicyouth.org/PopUps/WorkingPapers/WP45LevineYouniss.pdf (20. 03. 2013).

Lopez, M. and Marcelo, K. (2008). The civic engagement of immigrant youth: new evidence from the 2006 civic and political health of the nation survey, Applied Development Science, 12 (2): 66-73, doi: 10.1080/10888690801997051.

Perez, W., Espinoza, R., Ramos, K., Coronado, H. and Cortes, R. (2010). Civic engagement patterns of undocumented Mexican students, Journal of Hispanic Higher Education, 9 (3): 245-265, doi: 10.1177/1538192710371007.

Ronan, B. (2004). Testimony at the White House Conference on Aging Public Forum on Civic Engagement in an Older America, Phoenix, Arizona, 25 February 2004.

Rumbaut, R. G. (2000). Children of immigrants and their achievement: The role of family, acculturation, social class, gender, ethnicity, and school contexts, http://www.ksg.harvard. edu/inequality/Seminar/Papers/Rumbaut2.pdf (02. 08. 2013).

Schulz, W., Ainley, J., Fraillon, J., Kerr, D. and Losito, B. (2009). ICCS 2009 International Report: Civic knowledge, attitudes, and engagement among lower-secondary school students in 38 countries. Amsterdam: International Association for the Evaluation of Educational Achievement (IEA).

Shum, M. S-K., Gao, F. and Tsung, L. (2012). Unlocking the racialized and gendered educational experiences of South Asian females in Hong Kong: The case study of Pakistani girls, Asian Ethnicity, 13 (3): 251-262, doi:10.1080/14631369.2012.630570.

Skinner, E. A. and Belmont, M. J. (1993). Motivation in the classroom: Reciprocal effects of teacher behavior and student engagement across the school year, Journal of Educational Psychology, 85 (4): 571-581, doi: 10.1037//0022-0663.85.4.571.

Stepick, A. (2005). God is apparently not dead: The obvious, the emergent, \& the unknown in immigrant and religion, in: K. Leonard et al. (eds). Immigrant faiths: Transforming religious life in America. Lanham: Alta Mira Press, 11-37.

Stepick, A., Stepick, C. and Labissiere, Y. (2008). South Florida's immigrant youth and civic engagement: Major engagement: minor differences, Applied Development Science, 12 (2): 57-65, doi: 10.1080/10888690801997036.

Syvertsen, A., Flanagan, C. and Stout, M. (2007). Best practices in civic education: changes in students' civic outcomes, CIRCLE Working Paper, 57.

Torney-Purta, J. (2002). The school's role in developing civic engagement: A study of adolescents in twenty-eight countries, Applied Developmental Science, 6 (4): 203-212, doi: 10.1207/S1532480XADS0604_7.

Tsui, W. (2013). [South Asian problem kids in Hong Kong] (in Chinese), Next Magazine, 18 July 2013.

Tsung, L., Zhang, Q. Y. and Cruickshank, K. (2010). Access to majority language and educational outcomes: South Asian background students in postcolonial Hong Kong, Diaspora, Indigenous, and Minority Education: Studies of Migration, Integration, Equity, and Cultural Survival, 4 (1): 17-32, doi: 10.1080/15595690903442256.

Van Benshoten, E. (2001). Civic engagement for people of all ages through national service (unpublished manuscript). 
Whiteley, P. (2012). Does citizenship education work? Evidence from a decade of citizenship education in secondary schools in England, Parliamentary Affairs (published online 13 December 2012), doi: 10.1093/pa/gss083.

Youniss, J., McLellan, J. and Mazer, B. (2001). Voluntary service, peer group orientation, and civic engagement, Journal of Adolescent Research, 16 (5): 456-467, doi: 10.1177/0743558401165003.

Yuen, Y. M. C. (2004a). The early experience of intercultural teacher education in Hong Kong, Intercultural Education, 15 (2): 153-166, doi: 10.1080/1467598042000225014.

Yuen, Y. M. C. (2004b). Home school collaboration for border-crossing students: Challenges and opportunities, Hong Kong Journal of Early Childhood, 3 (1): 30-34.

Yuen, Y. M. C. (2009). [The Eighteen Students] (in Chinese). Hong Kong: Current Literatures Press.

Yuen, Y. M. C. (2010a). Dimensions of diversity: Challenges to secondary school teachers with implications for intercultural teacher education, Teaching and Teacher Education, 26 (3): 732-741, doi: 10.1016/j.tate.2009.10.009.

Yuen, Y. M. C. (2010b). Assimilation, integration and the construction of identity: The experience of Chinese cross-boundary and newly arrived students in Hong Kong schools, Multicultural Education Review, 2 (2): 1-29.

Yuen, Y. M. C. (2011). Towards inclusion of cross-boundary students in education, policy and practice in Hong Kong, Journal of Education, Citizenship and Social Justice, 6 (3): 251-264, doi: 10.1177/1746197911417416.

Yuen, Y. M. C. and Lee, M. S. (2013). Mapping the Life Satisfaction of Adolescents in Hong Kong Secondary Schools with High Ethnic Concentration, Youth and Society (published online 23 September 2013), doi: 10.1177/0044118X13502060.

Yuen, Y. M. C. (2013). Ethnicity, level of study, gender, religious affiliation and life satisfaction of adolescents from diverse cultures in Hong Kong, Journal of Youth Studies, 16 (6): 776-791, doi: 10.1080/13676261.2012.756973.

The 2014 Policy Address: Support the Needy, Let Youth Flourish, Unleash Hong Kong's Potential, http://www.policyaddress.gov.hk/2014/eng/pdf/PA2014.pdf (20. 01. 2014). 


\title{
Angažiranost u školi i građanska angažiranost kao prediktori političkog djelovanja domicilnih kineskih i južnoazijskih adolescenata u Hong Kongu
}

\author{
Celeste Y. M. Yuen
}

\begin{abstract}
SAŽETAK
U radu se iznose rezultati velikog istraživanja o odnosu angažiranosti u školi i građanske angažiranosti te samopredodžbe o sudjelovanju u političkim aktivnostima učenika kineske etničke pripadnosti i južnoazijskih učenika imigranata u Hong Kongu. Podaci su prikupljeni na uzorku od 5574 učenika od šestoga do jedanaestoga razreda, u dobi od dvanaest do devetnaest godina. U procjeni angažiranosti u školi primijenjen je anketni upitnik za ispitivanje afektivne, biheviorističke i kognitivne dimenzije. Građanska angažiranost učenika mjerena je upitnikom ICCS za učenike (Schulz et al., 2009). Prije regresijskih analiza provedena je konfirmatorna faktorska analiza (CFA), a rezultati su pokazali da oba instrumenta imaju dobru konstruktnu valjanost i unutarnju konzistentnost. U skladu s primarnim ciljem istraživanja, rezultati MANOVA analize pokazuju značajne razlike među učeničkim skupinama u angažiranosti u školi, građanskom samouvjerenju i ponašanju. Prema dobivenim rezultatima južnoazijski učenici koji ne govore kineski (NCS) u većoj se mjeri priklanjaju svim mjerenim dimenzijama u oba upotrijebljena instrumenta nego domicilni Kinezi i novopridošli učenici iz kontinentalne Kine. Rezultati hijerarhijskih regresijskih analiza potvrdili su da je angažiranost u školi značajni prediktor očekivane političke aktivnosti. Učinci angažiranosti u školi i građanske angažiranosti na buduće političko djelovanje značajno su varirali između svih anketiranih grupa.
\end{abstract}

KLJUČNE RIJEČI: angažiranost u školi, građanska angažiranost, političko djelovanje, domicilni Kinezi, imigranti, adolescenti, Hong Kong 